\title{
JOGO, LINGUAGEM, ENQUADRAMENTO: REFLEXÕES SOBRE O ATOR
}

\author{
Rejane Kasting Arruda \\ Doutora pela Universidade de São Paulo \\ Professora no curso de Artes Cênicas da Universidade Vila Velha \\ E-mail: rejane.arruda@usp.br
}

Em ressonância com a práxis desenvolvida em sucessivos processos de criação, onde a Pedagogia do Teatro está em questão, propõe-se uma orientação para a prática atoral fundamenta no que chamamos de "hipótese do arranjo". Para sustentá-la, utiliza-se proposições de Spolin e Stanislavski, bem como uma interface com outras áreas do conhecimento, como a Psicanálise e a Linguística de Ferdinand Sausurre. Acaba-se evidenciando um enlaçamento do ator com a linguagem durante o jogo de construção da poética cênica.

\section{Palavras-chave}

Ator. Criação Cênica. Jogo Teatral. Pedagogia do Teatro
At resonance with the practice developed in successive creation processes where the Theatre Pedagogy is in question, we proposes a guidance of the actor's practice based on the hypothesis of arrangement. To defend it, we use Spolin and Stanislavski's propositions, and an interface with psychoanalysis and the french linguist Ferdinand de Saussure. We just showing the actor's bonding with the language during the theatrical play of scenic poetic construction. Keywords

Actor. Scenic Creation. Theatrical Play. Theatre Pedagogy 


\section{Introdução}

Viola Spolin sistematizou uma prática de improvisação fundamentando-a em instâncias como: a regra (é a presença da regra que garante a espontaneidade no jogo), o foco (que pode se dividido e graças a esta divisão $o$ ator se torna vivo) e a resolução do problema (que, segundo ela, causa uma "explosão orgânica"). A sua teoria pode ser encontrada nos quatro livros traduzidos para o português que circunscrevem a sua obra: Improvisação para o Teatro (1978), O Jogo Teatral no Livro do Diretor (2000), Jogos Teatrais: O Fichário de Viola Spolin (2000), Jogos Teatrais na Sala de Aula (2007).

Em Exposição, primeiro jogo descrito no Fichário de Viola Spolin, pede-se para que o ator se mantenha em pé, diante da platéia, "sem fazer nada" durante um minuto. Spolin o utiliza para transmitir a importância do foco. Primeiramente, "desfocado", o ator se deixa assolapar pela timidez. Em um segundo momento, ao ser instalado o foco "contar as cadeiras do auditório", o corpo se acalma e o ator consegue parar de rir, tremer, se contorcer, etc. Com a "voz de jogo", Spolin instala um material: "Conte as cadeiras do auditório" (uma instância verbal, uma frase).

Qualquer material que se possa isolar, recortar com a linguagem (qualquer significante) pode entrar no foco. Mas existem também aqueles materiais que não são colocados intencionalmente no foco e se mantém "presentes na ausência" - uma ideia que postulamos ao articular o pensamento de Sausurre à Teria do Ator.

Fernand Saussurre, pai da Lingüistica Estrutural, em seu "Curso de Linguística Geral" (s.d.) produziu um verdadeiro tratado sobre a linguagem, sistematizando dois eixos funda- mentais: vertical e horizontal - e postulando o eixo vertical como empilhamento de presenças na ausência (significantes). Significantes são materiais que se fazem constituir pela sua diferença em relação a todos os outros do sistema. Não existe um significante que define o outro portanto (os significantes terão sempre uma relação de diferença entre eles).

O psicanalista Jacques Lacan posteriormente se apropriou desta ideia, para defender duas operações fundamentais da linguagem: a metáfora (que articula a ideia de empilhamento, o estar a um só tempo, o substituir um ao outro no eixo vertical) e a metonímia (como deslizamento, deslocamento de fragmentos ou significantes no eixo horizontal). Lacan promove um "retorno a Freud", retomando as suas ideias de condensação e metonímia, a sua estrutura de linguagem, a sua ideia de inconsciente - criando novos postulados, conceitos e constituindo uma nova formalização da prática psicanalítica (LACAN, 2007; 1996).

Que os materiais do ator possam estar empilhados, com suas reverberações, a ressonar no corpo: esta é uma proposição que queremos desenvolver, acreditando que possa nos ajudar a pensar o trabalho criativo, nos munindo de instrumentos para falar sobre as suas operações. $O$ que $O$ ator escuta (ou percebe) da sua "situação de jogo", também é "uma diferença", um significante, a articular-se com outros e causar-Ihes a excitabilidade, ressonando na tessitura corporal e a fazendo vibrar, tal como um instrumento musical, alterando as resultantes do jogo: as ações físicas.

Os materiais que fazem parte do próprio contexto (o estar em cena) provocam, aderem e imprimem. Ações físicas são resultantes de um complexo jogo, portanto, de empilhamentos e deslocamentos (linguagem). Quando o ator vê, 
quando consegue deter o olhar em sua produção, esta já foi impressa; o corpo já sofreu a excitabilidade e a ação física já está encenada. Assim, é possível não controlar, mas "manejar" o processo de produção a partir do jogo; é o que defendemos. Mas é preciso ver como isto se dá; quais as operações envolvidas.

\section{A Noção de Enquadramento}

Desenvolvendo nossa hipótese, seria preciso materiais que, arranjados com outros, organizem o corpo no tempo e espaço. A esta função poderemos chamar de "enquadramento". No primeiro jogo do Fichário de Viola Spolin já citado (Exposição), quando o instrutor introduz a frase "conte as cadeiras do auditório", o corpo se acalma, ou seja, se organiza; meIhor dizendo, é "enquadrado" na relação com a voz que conta: "uma, duas, três cadeiras no auditório". Uma cadeia verbal, acústica, é capaz de organizar o tempo, pois situa um trilho de elementos diferenciais (no caso "um, dois, três") em sequência. Assim, consegue-se sustentar a cena do corpo para o olhar do outro. O material (voz interna) conduz a organização temporal na medida em que se desdobra em uma sequência: "um, dois, três, quatro cadeiras". Este trilho acústico entra no foco de atenção, organizando ressonâncias no corpo, que são atualizadas. O corpo presentifica certo tempo-ritmo (Stanislavski, 2009). Um espaço de vulnerabilidade se abre: a tessitura corporal com os seus ecos, vibrações e afetos é contornada, enquadrada, enquanto o ator sofre a incidência desta voz e de todo um arranjo, que conta com esta para situar as ações físicas no espaço-tempo.

Uma partitura física já constituída pode, também, enquadrar, enquanto outro mate- rial a pressiona, desorganizando seu espaçotempo? Com outras ressonâncias e trazendo novas resultantes? A partitura física sendo apenas um dos materiais do arranjo? Existiria outras plasticidades neste arranjo? Outros enquadramentos? Da parte do espectador, o seu olhar não enquadraria ou situaria a produção corporal do ator? Considerando as associações que a produção atoral pode suscitar neste espectador, o seu olhar enquadra, organiza, situa, em um mundo seu, esta produção cênica?

Interessa-nos o processo de produção poética quando se trata do trabalho com a dramaturgia (texto-de-autor, dramático se considerarmos o termo no sentido da peça escrita para o teatro). Quando se lida com a "posta em cena" (Pavis, 1999) exige-se, do ator, um manejo dos enquadramentos. A fala do texto dramático causa uma excitabilidade e a identificação imediata com algumas ações - que no entanto, através da Análise Ativa (Knebel, 2005) podem ser alteradas ou subvertidas a partir de um novo olhar. É preciso constituir uma poética da cena que não se restrinja à representação das ações interpretadas na escuta do texto. Isto não quer dizer que a poética necessariamente deva ser constituída com o corpo treinado para ser extra-cotidiano (Barba, 1994). Não se trata de evitar a visualidade do campo da realidade, com sua plasticidade comum, como advoga a práxis do Teatro Físico ou outras que assumem o discurso antidramático. Apesar de se testemunhar a importância de um repertório extra-cotidiano, seria possível elevar a produção de um ator não treinado ao estatuto de poiesis, jogando também com a cotidianidade, pois existem outras modalidades de enquadramento.

O corpo extra-cotidiano incorpora uma 
plasticidade que se configura como uma das modalidades possíveis de enquadramento para que uma poética da cena aconteça. No entanto, pode-se constituir poéticas que não são fundamentadas no corpo extra-cotidiano. Neste sentido, a produção de cotidianidade necessita de baixo tônus, de "não fazer", "nada fazer" - para o qual um iniciante pode se demonstrar mais apto, inclusive (conforme foco de atenção e instrução de jogo). Trata-se de manejo, portanto, para que uma plástica (enquadramento) se constitua, seja extra-cotidianidade ou cotidianidade, elevada ao estatuto de poética conforme o jogo de enquadramentos. Nesse caso, são modalidades de enquadramento diferentes.

\section{As Artes Plásticas:} Uma Modalidade de Enquadramento

A plasticidade de materiais extraídos das Artes Plásticas pode significar uma maneira de treinar os atores para se tornarem extra-cotidianos. A figura extraída das Artes Plásticas media a criação corporal, oferecendo um enquadramento possível (organização no espaço e tempo) para que se produza uma poética do desenho. $O$ ator não apenas interpreta o texto, mas atua em direção a uma plástica estranhada que tantos defenderam: Craig, Kantor, Meyehold, Barba, Wilson. São desenhos mais ou menos precisos, mais ou menos disformes, mais ou menos abstratos, conforme a poética. Esta poética do desenho aposta no que não é familiar, tornando-se também uma poética do estranho.

O trabalho com o material iconográfico, ou seja, a imagem extraída da obra de um pintor, revista, fotografia, filme, etc, deixa clara a função do enquadramento plástico- corporal que, no entanto, pode ser também exercida pela cotidianidade. Esta, por sua vez, em sua simplicidade, se faz poética quando, no entanto, algo se introduz como perturbação e aparece um segundo enquadramento: a visualidade de um pensamento e olhar "do personagem". O personagem pode ser, assim, tomado como "figura" da ficção que se evoca, construída como efeito da cena. Preparamos a defesa de um realismo, no sentido da mimese da cotidianidade enquadrada pela visualidade da ficção "como se fosse real", também como uma modalidade poética possível. Esta modalidade se dá pelo jogo entre enquadramentos diferentes: a visualidade do pensamento, a cotidianidade e a ficção.

\section{O Enquadramento Temporal}

Existem outros enquadramentos. A música não implica, de antemão, limites para as bordas corporais. Mas incide no entanto sobre o ator, organizando o tempo. No caso do enquadre constituído a partir do som, o ator estará livre para constituir um desenho do corpo através das atualizações da tessitura interna corporal, que acorda e atualiza as suas formas, marcadas anteriormente. Na medida em que a memória corporal é atualizada, esta se constitui como um desenho mais ou menos preciso. Além da incidência do material que situa o foco de atenção (escuta) naquele momento, estão, no arranjo, incidências revividas de materiais antigos que já fazem parte da história daquele corpo.

\section{O Personagem como Enquadramento}

Da mesma forma que a música não enqua- 
dra o espaço, mas sim o tempo, existem outros materiais que não enquadram nem espaço nem tempo. Ao contrário, bagunçam. O que se conclui é que se trata de um arranjo complexo: enquanto um material enquadra o tempo, outro enquadra o espaço, outro faz ressonar a memória corporal, atualizando ecos sem que o ator se dê conta, ou seja, bagunçando. O uso de materiais diferentes deixa entrever funções diferentes: incidência, enquadramento e a memória que se abre e carrega o ator (função que chamamos de "vulnerabilidade"). A tessitura interna do corpo se abre e "leva" o ator.

Muitas vezes, o ator iniciante diz que está sendo "levado" pelo personagem, justamente porque não vê o que acontece no interior do seu corpo e o fenômeno lhe é tão estranho que parece estar sendo provocado por outro. O fenômeno não envolve o seu olhar; tratase de algo que não brota de sua intencionalidade: trata-se, então, de fricção de corpos, enquanto o foco de atenção está situado em outro lugar, dividido com a percepção da produção que está sendo impressa em cena. É como se não fosse ele próprio agindo, pois é "empurrado" por algo que acontece no corpo, à sua revelia. Trata-se de uma força estranha, enquanto a cena veicula significantes que, em escuta, são associados ao "efeito-personagem". Personagem que, por sua vez, depende de uma montagem realizada pelo espectador, através do seu próprio olhar e associações. $O$ personagem é resultante do jogo de enquadramentos. Existe uma camada de visualidade, composta pelas ações da personagem. Não ações físicas, mas as ações dramáticas, situadas na diegese e que podem coincidir ou não com as ações físicas (elas podem se descolar, produzindo estranhamento). O personagem escutado no texto faz incidência no ator, mas o que o espectador está lendo não é o texto e sim a cena, ou seja, a escrita da encenação. É outro discurso, o cênico, que implica desenhos e, também, aquilo que o ator atualiza sem querer. Entre a percepção do foco, que o foco recorta, e o enquadramento, a memória corporal ressona e se abre. Um complexo jogo. A excitabilidade é provocada por materiais que recortam ou isolam a incidência, que já está naquele corpo de maneira amorfa, sem forma, acionada por caminhos invisíveis dentro da tessitura de memória ou pelo simples fato do ator "ser" para o olhar do outro. Esta "massa" precisa ser recortada, desenhada.

\section{Outro Conceito de Corpo}

A Psicanálise surge com Freud na virada do Século XIXI para o XX centrada na idéia de inconsciente e revela-se enquanto um campo de saber, com objetos próprios e hipóteses. A Psicanálise (principalmente a Pscicanálise lacaniana) acusa uma articulação entre o verbo e o corpo, a linguagem e o inconsciente. Lacan vai de encontro a Freud, construindo novos conceitos na medida em que dialoga com outros campos do saber, como a Antropologia, a Teoria dos Conjuntos (Matemática), a Filosofia, a Lingüística.

Com o neologismo falasser, ele se refere à sustentação do sujeito no ser que fala, que usa a linguagem. Aparece uma relação problemática com o "ter" um corpo, abrindo a perspectiva de se pensar outras noções de corpo: "O falasser adora seu corpo, porque crê que o tem. $\mathrm{Na}$ realidade, ele não o tem, mas seu corpo é sua única consistência, consistência mental, é claro, pois seu corpo sai fora a todo instante (...)" (Lacan, 2007, p. 64). O corpo aparece como "conjunto vazio" - ou "um a mais" (e não 
como a identidade do sujeito).

O corpo é para Aristóteles, aponta Lacan em Mais, ainda, o modelo do um. Mas esse um é o indivíduo, isto é, o um-todo-só. E cabe a Lacan interrogar então sobre a origem verdadeira do significante Um (p. 196-7; ed. fr. p. 130-1). (...) o corpo poderia ser o modelo, ou seja, a origem imaginária, não do um-todo-só, que é significante, marca, traço, corte, mas do um-a-mais que é o conjunto vazio (Miller, 2007, p. 213-214).

É como se o corpo estivesse a mais ao sujeito, só que este a mais é vazio e, tal como uma lata vazia, ele fizesse eco.

Trata-se de dizer, simplesmente, que o corpo existe como um saco de pele, vazio, fora e ao lado de seus órgãos. (...) Sua ex-sistência aos elementos que ele contém, sua consistência de continente é a do conjunto vazio na fórmula: $\{1, \varnothing \dot{\varnothing}\}$ (Miller, 2007, p. 213214).

Na psicanálise, o corpo é também o suporte do inconsciente, na medida em que é nele que "a linguagem copula": "(...) o sentido como tal, definido pela copulação da linguagem, posto que é a partir dela que dou suporte ao inconsciente, com nosso próprio corpo" (Lacan, 2007, p. 118). Corpo enquanto "saco", que imaginariamente dá unidade a uma imagem de si, onde ecos são percorridos, implicados como um "modo de gozo", irredutível daquele corpo. Corpo como lugar onde "a fala goza": "na medida em que, no sujeito que se sustenta no falasser há a capacidade de conjugar a fala e o que concerne a um certo gozo" (Lacan, 2007, p. 55). Gozo como excesso; gozo como repetição; gozo como estilo; gozo como escrita; gozo como êxtase; gozo que seria puro na morte; gozo como angústia; como contato com um real indizível; traumático gozo como sem-sentido: são diversas as figurações do gozo que aparecem na obra de Lacan.

Nos aventuramos a trazer estas ideias para a investigação sobre o ator em cena. Pode-se dizer que ele treme, tal como um ser apaixonado; pode-se dizer que o saco vazio é encharcado, sujeito às contingências dos encontros entre os diversos materiais que compõem a especificidade da sua memória, articulados a uma forma de gozo daquele corpo. É como se não fosse possível escapar da especificidade da própria história, fantasia e, também, da pessoalidade, apesar das paixões de Artaud, Craig, Meyerhold, pela impessoalidade. É necessária a morte da pessoalidade para que uma poética surja? E quando se advoga a impressão do "humano" - sendo este um dos paradoxos da poética cênica - postulando-se um humano-morto? E quando se fala de "realismo" ou "cotidianidade", do seu automatismo, pode-se trabalhar certa impessoalidade, também? Ainda que cada sujeito implique as marcas inerentes do seu corpo-linguagem, as letras de uma história de afetos? Ainda que, para além de uma estrutura que o determina às avessas, esteja a contingência do "fora do sentido" com o qual ele se enlace: este tal gozo, do qual o ator tenta se defender ou que vive em sua fantasia. Tal como um Genet, quando coloca a paixão pela morte em cena; como Kantor, Craig, Meyerhold, que colocam o boneco (morto do homem) em cena, o ator vive uma fantasia de morte. Quando trabalha a fé cênica (Stanislavski, 2005) para dar lugar a outro, é de si que, imaginariamente, abre mão. $\mathrm{O}$ "dentro de si" é constituído em nome do "pensamento da personagem" enquanto "fora de si" ele produz o "corpo da personagem". Nesta fantasia de ser outro, ele joga com toda a sua estrutura: 
linguagem, corpo, vazio, memória.

\section{Algo do Verbo que Escapa \\ à Linguagem}

A paixão de Artaud pelo som em detrimento do sentido pode expressar algo da alingua, tecido de pedaços de som a nível a-estrutural, caos: "Alíngua é o nível a-estrutural do apareIho verbal, ao passo que a linguagem e o discurso são ordenações" (Coler, 2010, p. 16-17).

Lalação vem do latim "lallare", que designa o fato de cantar "lá, lá..." para adormecer as crianças, dizem os dicionários. Designa o balbucio da criança que ainda não fala, mas que já produz sons. A lalação é o som separado do sentido, mas como se sabe, entretanto, não separado do estado de contentamento. (...) Os efeitos dessa alíngua ultrapassam, e muito, tudo aquilo que dela podemos apreender. Esses efeitos são os afetos, no sentido em que é a alíngua que afeta primariamente o gozo. (...) Que se possa gozar da matéria verbal, é algo assegurado pela existência do poeta (Lacan, 2007, p. 118)

Como o ator brinca com a corporeidade dos sons, dos cacos, dos saltos? Também a fantasia une e dá unidade a alguma ordem pulsional, fazendo do outro um objeto do gozo da sua fala. As imagens das pessoas são tecidos de onde o ator recorta significantes, que entram, por sua vez, no seu discurso e arranjo, fazendo ressonar, no "saco vazio", o "singular" do qual é efeito. A produção atoral é resultante destes ecos (sujeito partido e um corpo vazio), encharcados do gozo da alingua e do tecido de cicatrizes da linguagem, sob a chancela da fantasia que diz da sua verdade. Se a criação é singular, estruturalmente traz consigo algo que não amarra diretamente o sentido da cena (representação), mas se revela enquanto estilo próprio. Assim se é artista, tem-se sempre uma versão própria do personagem e as ações físicas determinadas pelas repetições de um modo-de-gozo.

\section{A Linguagem, do que é Feita?}

Cada material se encontra em relação de diferença com outros. A linguagem é um sistema de diferenças organizado em dois eixos: o eixo horizontal (sucessão) e o eixo vertical (empiIhamentos).

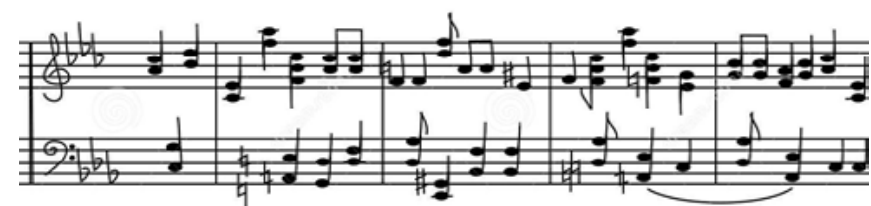

Figura 1: Pauta Musical

A estrutura da relação entre as notas está em jogo: pela a ausência daquelas que não aparecem na escrita musical, mas estão na escala do dó ou do si. Quando colocada em funcionamento, significantes, sejam notas ou materiais, podem deslizar de um empilhamento para o eixo horizontal, formando a melodia, em sucessão com outros.

O eixo vertical denota uma relação metafórica: uma coisa no lugar de uma outra. O horizontal indica metonímia: um deslizamento, uma escorregada. Os elementos deslizam na linha melódica; vão de um lugar a outro. Assim, as operações de sustentação da linguagem são metáfora e metonímia (substituição e deslocamento) e não as relações diretas entre significados e significantes, como se a linguagem fosse um dicionário.

Em voga nos anos 1960, a noção de escritu- 
ra cênica enquanto um amontoado de signos, onde cada elemento significa algo, entrou em colapso. Fato importante para a práxis da posta em cena, pois nos ensinou a não reduzirmos nossa criação aos significados do texto. Construímos uma outra escrita e o texto dramático está como um dos materiais apenas. O texto falado se organiza com as ações físicas. A noção de enquadramento nos permite pensar esta relação como um jogo de enquadramentos complexo e difícil, entre a presença da palavra a visualidade das ações físicas, ambas evocando ações dramáticas distintas. As visualidades das ações dramáticas evocadas pela palavra e corpo se justapõem, opõem, compõem. A organização espaço-temporal entra em jogo: um sobre o outro, em oposição ou justaposição, em síntese, harmonia ou dissonância. A lei do arranjo é também lei da composição. Materiais cuja incidência banha o corpo e atualiza o seu modo de gozo são utilizados para trazer à tona o seu tecido ressonante e o estilo do ator. $O$ que não se aplica à equação ainda assim faz efeito aos olhos.

\section{A Incidência do Material}

Encontra-se o termo incidência em Lacan denotando um efeito de inscrição do significante no corpo. Trazemos da Física o termo "ângulo de incidência", junto à imagem de um raio de sol incidindo na pele, tocando, fazendo-se inscrever ou seja, entrar, afetar, marcar.

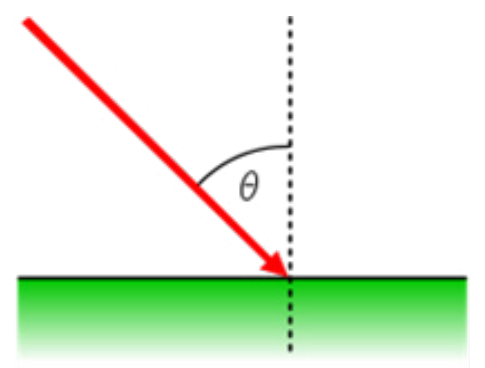

Figura 2: Ângulo de Incidência
Para Lacan, o gozo marca o significante no corpo, pois faz significar "aquela parte": “(...) uma parte que, do corpo, é significada nesse depósito. (...) Nisso que ele é termo, o significante é aquilo que faz alto ao gozo" (Lacan, 1996, p. 36). Esta proposição aponta a perspectiva de construir um corpo cênico com a linguagem, na medida em que cada parte é significada e se constitui como diferença quando se recorta, isola, monta, incidindo. O material que incide é da ordem do simbólico: "Por que é que damos tanta ênfase à função do significante? Porque é o fundamento da dimensão do simbólico" (Lacan, 1996, p. 32). O "material" - algo que pode ser nomeado, está na linguagem - incide, construindo corpo cênico, expressivo.

Na práxis teatral, os materiais de ator são chamados estímulos por Stanislavski (2005). No entanto, no trabalho do ator, não se trata de resposta a um estímulo, tal como um órgão estimulado responde ao tratamento - ou como a reação de fechar as pálpebras frente a uma ameaça (estímulo) de algo entrar nos olhos. Neste caso, todos reagem da mesma maneira: fechando os olhos. Na criação atoral não se sabe da ação resultante, porque há o modo de gozo de cada um, que produz algo específico na poética da cena. Reconhece-se a imprevisibilidade e contingência do processo. A ação física implica um indizível (gozo) junto a materiais que, enquanto diferenças articuladas, fazem eco. É como se o material fosse acachapado no corpo, tal como uma bola de basquete na rede, bem no ponto de incidência. Substituímos, assim, a ideia de reação ao estímulo pela ideia de uma incidência contingente do material no corpo que produz cena. 


\section{O Recorte do Olhar}

$\mathrm{Na}$ estrutura do trabalho do ator, há também encadeamento: materiais "deitados" no tempo horizontal da cena. O que cabe no seu olhar? O seu olhar desliza entre os materiais que vai recortando, agilmente, tal como uma câmera de cinema, que se abre e transita pela superfície da cena. É o que se percebe na proposição de Grotowski abaixo.

(...) eu penso no canto dos olhos, a mão tem um certo ritmo, vejo minha mão com meus olhos, do lado dos meus olhos quando falo minha mão faz um certo ritmo, procuro concentrar-me e não olhar para o grande movimento de leques (referência às pessoas se abanando no auditório) e num certo ponto olho para certos rostos, isto é uma ação. Quando disse olho, identifico uma pessoa, não para vocês, mas para mim mesmo, porque eu a estou observando e me perguntando onde já a encontrei. Vejam a posição da cabeça e da mão mudou, porque fazemos uma projeção da imagem no espaço; primeiro esta pessoa aqui, onde a encontrei, em qualquer lugar a encontrei, qualquer parte do espaço e agora capto o olhar (...) (Grotowski, 1998, p. 1)

Os materiais que o olhar do ator recorta são significantes, são diferenças se substituindo e o movimento do olhar no tempo os coloca horizontalmente. Enquanto uma ponta do foco desliza em sucessões, na horizontalidade da cena, a outra ponta está situada em uma pequena parte da ação física, nas bordas do próprio corpo, que apenas se entrevê. O restante, não se pode capturar. $O$ foco é uma função na medida em que algo dele sempre escapa. $O$ que se recorta se torna material, mas a ação física é, em grande parte, inapreensível através deste olhar-linguagem que recorta uma super- fície do real.

Segundo Spolin, é graças à divisão-de-foco que o espontâneo acontece (Spolin, 2010). O brotar do corpo, espontaneamente, só pode se realizar porque o ator está concentrado, com o foco grudado em outro lugar: uma regra-de-jogo, uma instrução-de-jogo. Por isso, o importante não é que a regra seja cumprida, mas que o ator se mantenha em relação com a sua presença, para que o foco permaneça dividido. A espontaneidade acontece na medida em que a produção corporal "sai do foco". O corpo vai, estufa, preenche o espaço-tempo delimitado do enquadramento.

O que interessa ao ateliê da criação atoral é a perspectiva de despertar ecos impregnados na tessitura, uma malha de atravessamentos do corpo, na medida em que este é vacúolo vibrante, atualizando o singular e, ao mesmo tempo, desenhando-o. A ação física oferece as bordas, os limites para efeitos diversos de reverberação. A hipótese do arranjo de materiais e jogo de enquadramentos ganha força ao se ler a teoria o ator. Certas descrições mostram uma incidência insistente de significantes, como "preciso", por exemplo. A palavra pode ser marcada como instrução de jogo e o ator se acostuma a ser preciso, criando uma "segunda natureza" (Stanislavski, 2009): a sua natureza cênica.

\section{Guerra de Enquadramentos}

Encontramos palavra, fala externa, movimento como dois enquadramentos que disputam a superfície de um corpo: como se a impureza de um fosse necessária para este "caber" no outro (ou para que os dois caibam em um terceiro). Deparamo-nos com a perspectiva de um enquadramento enquadrar o outro. 


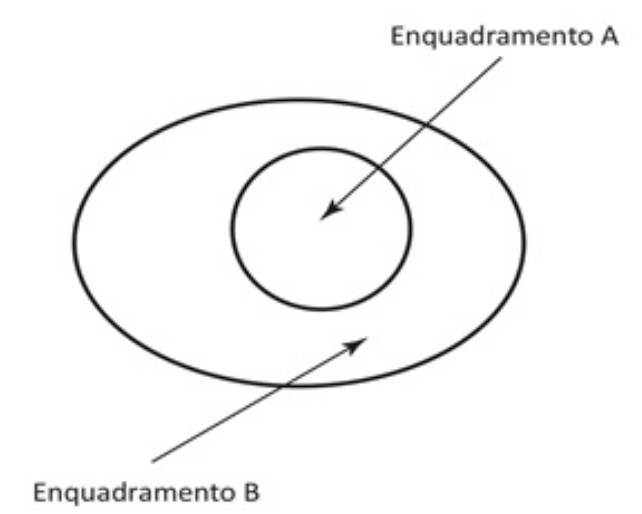

Figura 3: Um enquadramento enquadra outro

No caso da utilização de figuras das Artes Plásticas para enquadrar o corpo do ator, lança-se mão de material oculto para desenhar bordas. O "pulo do gato" é quando esta é atualizada via tessitura interna em jogo com outros enquadramentos. Este "sem pensar" indica um automatismo, mas também uma organicidade. A forma se adéqua, é absorvida por outro enquadramento, sendo que o foco não está mais nela, e sim nos materiais de absorção: a relação com o outro ou a ação sobre o outro ${ }^{1}$ por exemplo. Utilizando a figura abaixo para refletir este processo, ao invés de uma imagem extraída das Artes Plásticas ser utilizada na área verde (propositadamente como forma que organiza o corpo) ela retorna, sem querer, na área rosa (o "dentro" do corpo quando temos outra coisa enquadrando). O que ocupa a área verde é a "ação sobre o outro", a relação com o outro, cuja percepção situa-se no foco.

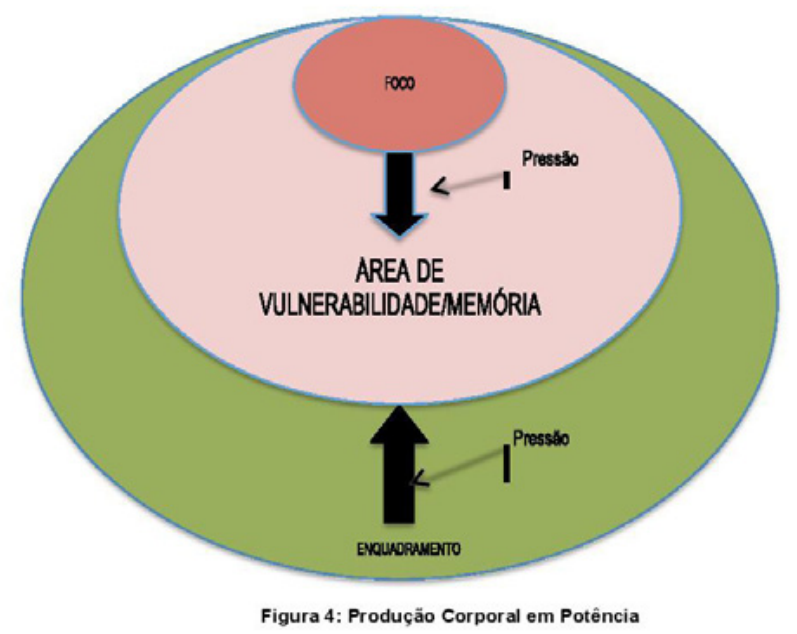

Figura 4: Produção Corporal em Potência

A imagem já marcada no corpo retorna na tessitura corporal, fora do foco, moldando-se ao enquadre que está lá, na área verde. $O$ enquadramento na área verde pode ser os limites espaciais ou oferecidos por um figurino, objeto, pela relação com o outro, seja ela ficcional, imaginária, personagem ou contexto de jogo, a relação com um material utilizado como substituição (Hagen, 2010) ou mesmo uma frase ou palavra, concepção da personagem. Tal como com as figuras das Artes Plásticas, pode-se utilizar o desenho do movimento abstrato extraído de um Teatro Performativo de Bausch ou de outra cena pós-dramática. Mantendo-o intacto, ele funciona como uma citação, se é reconhecido. Mas, borrando-o, pode-se transformá-lo em outra coisa. O pintor contemporâneo Glenn Brown utiliza-se da pintura de outros como material determinante. A visualidade do original é exposta, mas a nova produção é autoral.

10 termo é escutado frequentemente em práxis de escolas de orientação stanislavskiana, apesar de não estar citado sistematicamente ou problematizado formalmente em sua obra. 

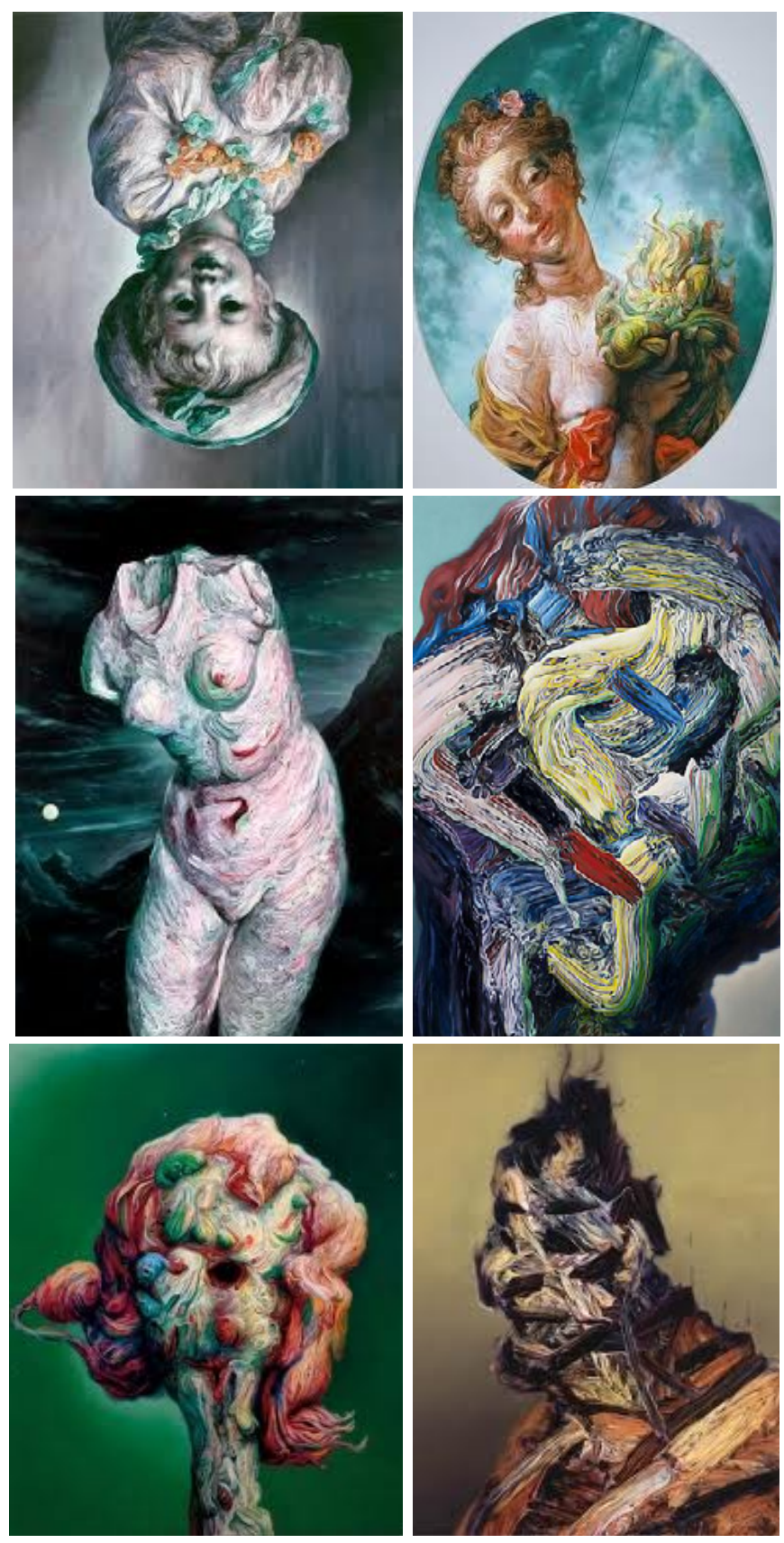

Figura 5: Obra de Glenn Brown

No caso do pintor, a produção não está impressa no corpo, como acontece com o ator. No caso do ator, a carne é tela que traz protuberâncias, marcas, ecos, estilo. A tendência é, na medida da incorporação, transformar e absorver a imagem de partida. Em Stanislavski, um treinamento acaba por formar a "segunda natureza", termo utilizado por Barba a respeito do corpo extra-cotidiano, que se treina, e por Adler em relação ao registro corporal da coti- dianidade, que se treina também.

Diz respeito ao modo pelo qual cada ator reinventa seu próprio corpo para tornar possível o exercício da linguagem teatral. Fundamentalmente, refere- se a uma transformação psicofísica, que torna possível a experiência da vida cênica. A expressão "segunda natureza" (Ruffini, 2007), cunhada pelo diretor russo Constantin Stanislavski, diz respeito à forma pela qual o ator precisa reaprender as ações que aprendeu no seu cotidiano, de modo a construir outra "natureza corporal" (Alcântara, 2013, p. 909-910).

Considera-se que se pode se instalar o registro do corpo cotidiano treinado na fissura entre outros enquadramentos e aquelas incidências que situam o foco. É preciso materiais para impregnar o corpo de cotidianidade, pois se não há materiais, o ator se depara com o vazio da cena e paralisa. Se não há materiais, não há como introduzir a cena do corpo, seja implicando plasticidade estranhada ou a cotidiana, íntima. A imagem abstrata das Artes Plásticas pode ser enquadrada com a escuta da imagem que produz uma associação, pois a visualidade da associação enquadra. $O$ mesmo acontece com a abstração corporal: provoca associações que situam a ação física e enquadram na fantasia, ou seja, na ficção. Mesmo que não se trate de uma construção unificada pela fábula, mas um fragmento solto, uma ação é criada/evocada com um corpo afetado e impresso singularmente.

É o que acontece em treinamentos barbianos $^{2}$. Começa-se pela abstração, ou seja, por atividades de puxar, lançar e empurrar organizadas tal como uma coreografia abstra-

2 Atores do Odin Teatret, companhia de Eugênio Barba, espalham modalidades de treinamento de ações físicas pelo mundo, trabalhando com grupos de teatro diversos. 
ta. Mas, de repente, se absorve a forma em outro enquadramento. O princípio do uso da abstração para se chegar ao sentido da ação abre possibilidades de jogo com frases auxiliares, pois ajudam a absorver a forma. Assim se constituem as ações dramáticas em cena. Mas o que ainda resta à ideia da ação? O que está para além do verbo-de-ação associado à forma do corpo impressa? O desenho corporal é um enquadramento em sua diferença; é outra coisa em relação a este verbo. E pode associar outras coisas também. Há espaço entre os enquadres, diferenças entre os enquadres, arranjo, composição. Nas fissuras entre eles, o espectador cria, trabalha, preenche.

Quando trabalhamos com o texto dramático, ações são evocadas nas entrelinhas das palavras. É possível escutá-las na leitura do texto dramático, no papel ou na tessitura cênica. Mas ações são evocadas também na medida em que o corpo "diz". Há, portanto, a possibilidade do corpo dizer uma coisa e a fala outra. Pode-se escutar nas entrelinhas das palavras coisas diferentes do que o corpo diz. $O$ ator pode construir repertório corporal para utilizar no momento da relação com o outro. Este material será auxiliar, retornando sem querer e absorvido na visualidade das ações, situadas nas entrelinhas das palavras, na ação sobre o outro, na relação do ator com as coisas. A relação do ator com as coisas é marcada, impressa na cena, pois faz parte do arranjo. Todo enquadramento implica uma plasticidade e as suas bordas, os seus limites.

A dramaturgia performativa valoriza a plasticidade de um eixo extra-ficcional, onde o contexto de realização da obra é tematizado. Ainda assim, há um imaginário sentido em jogo: o contexto do ator, o sentido da sua relação com $o$ ato cênico, o mundo, o outro. A imagem do "eu" em relação com "outros" implica imaginário, ou seja, um sentido, e identificação. Já a dramaturgia dramática enquadra a produção do ator na visualidade do mundo do personagem, com a sua lógica. Mas estamos produzindo poética e às vezes é necessário quebrar a lógica deste enquadramento em função do jogo com outros. A poética da cena não é algo que caiba em um discurso; ela é escritura. No caso da modificação do arranjo, teremos o enquadramento antigo no eixo vertical. EmpiIhamentos de arranjos cênicos: cada um que é abandonado deixa um resíduo e se faz sentir "presente na ausência" (Sausurre, s.d) apesar de não mais enquadrar a cena e sim o novo arranjo.

A plasticidade do cotidiano se estabelece como enquadramento quando o jogo implica atividades como abrir a porta, calçar a sandália, mexer na caneta. Uma sequência de ações físicas podem configurar as contra-ações fazendo oposição às ações internas. Certo arranjo também pode funcionar como contra-ação de outro - sendo que a resolução de jogo é a síntese, acordo ou alternância entre eles.

Plástico, o imaginário é bordado conforme novas associações e se transforma. As circunstâncias imaginárias permanecem em ebulição. "Surge, então, uma breve discrepância. $\mathrm{O}$ ator logo investiga, para ver qual é a parte que não está em ordem". (Stanislavski, 1989, p. 281). Como as associações internas, o enquadramento não está morto; se mexe. Mas a cena é fixada, escrita. Há um jogo de se deixar levar pelo fluxo das incidências dos enquadramentos. Se você treina, está sujeito ao fluxo de incidências de um enquadramento que se instala na área de vulnerabilidade (a área corde-rosa da Fig. 4), de maneira que a imagem da ação física não situe mais o foco. Algo novo 
se captura, em outro instante, e situa o foco ou o divide. Existe, portanto, o jogo de manejo do foco quando o ator se instiga com a imagem acústica que funciona como regra de jogo: precisão, dilatação do tempo, pequeno, grande, etc. A partitura física já desenhada e marcada deverá retornar na tessitura interna, sozinha, "sem pensar", pois o foco se deslocou para outros materiais.

O jogo cênico é vivido em nome próprio. No jogo dramático, o ator o disfarça, dá-lo a ver na plasticidade da personagem, inscrevendo as resultantes corporais na visualidade da diegese da fábula.

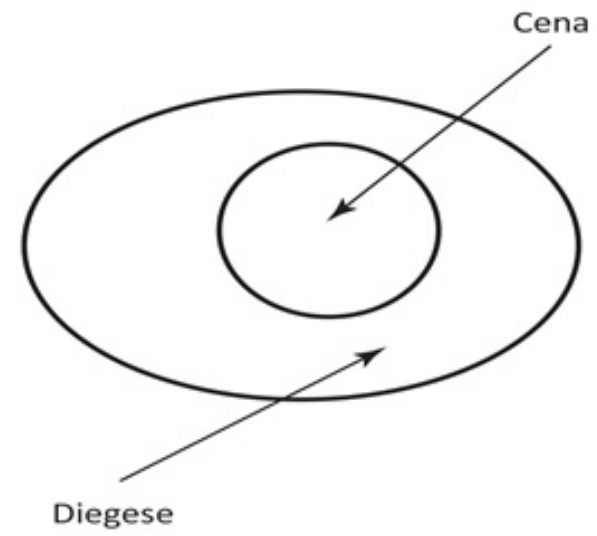

Figura 6: Enquadramento pela Diegese

O mundo ficcional é plástico. Ele também se modifica com o ato de ver de novo. A pulsão do olhar: ver o que não tínhamos visto - e sempre se descobre mais. O enquadramento fora do espaço cênico, na imaginação, poderia ser evocado com a palavra proferida na mesa de um bar, mas é evocado com o corpo. A imagem do corpo é inscrita na cadeia da ficção e entra em relação com as palavras situadas nesta mesma cadeia, ambos com valor de significante. O desenho corpo, ou seja, como o ator o situa no tempo-espaço, é um enquadramento, com plasticidade, capacidade de transformação e limites. A poética da ficção, onde se situa a ação dramática que pode ser compreendida, implica outro enquadramento, específico, com a sua própria plasticidade. A plasticidade do corpo e ficção se articula conforme o arranjo, ou se opõe. Novamente, há um jogo entre os enquadramentos. Da mesma maneira, o ator enquadra a sua fala no tempo-espaço ficcional. No entanto, se algo da música da voz resta à plasticidade da fábula, ela produzirá um efeito de estranhamento: há poéticas que não se utilizam da plasticidade da ficção, mas abusam da plasticidade da abstração do movimento ou voz, ou seja, privilegiam outras modalidades de enquadramento.

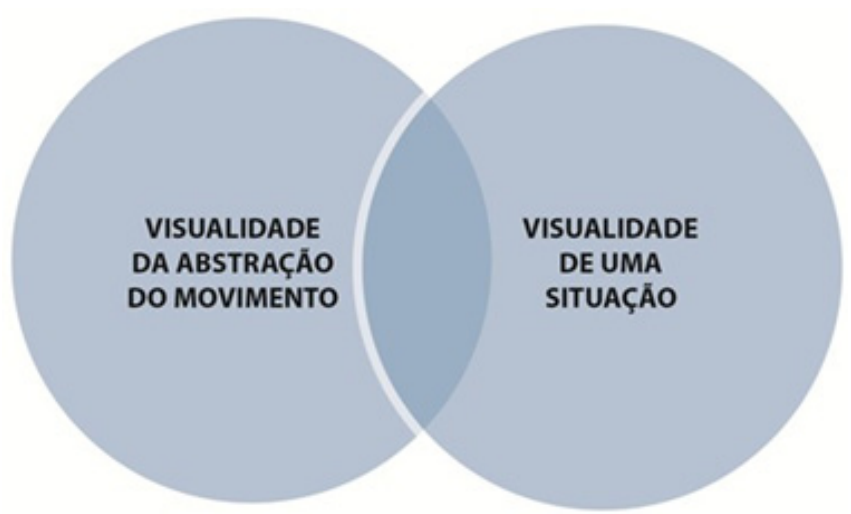

Figura 7: Articulação entre dois enquadramentos

Em algumas peças de Bob Wilson, o desenho do corpo nada tem a ver com as ações que as falas evocam, causando uma disjunção entre as duas camadas.

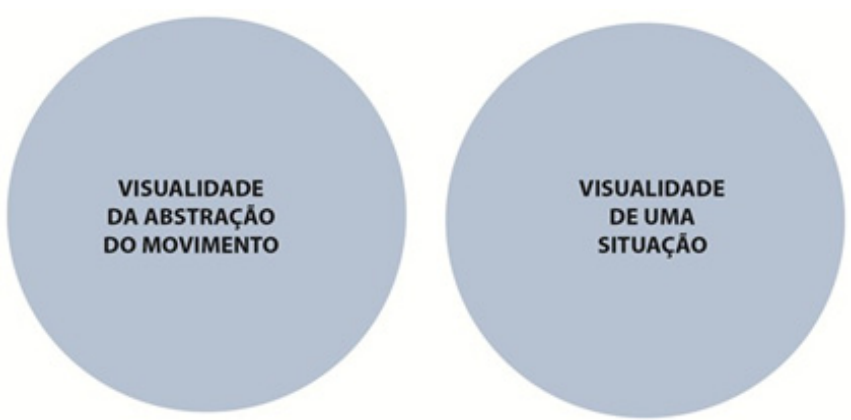

Figura 8: Disjunção entre as duas visualidades (da cena e da diegese) 


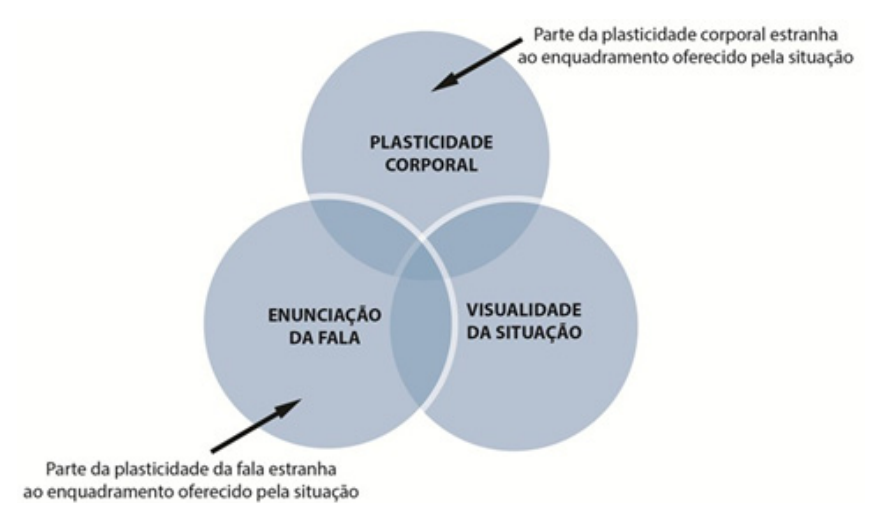

Figura 9: A parte que fica de fora do enquadramento da diegese estranha

A operação de absorção da abstração do movimento na visualidade de uma ação, ou da sonoridade da voz na visualidade da ação vocal, implica gradações. Há poéticas que contam com uma absorção intensa, quase total, de maneira que a visualidade da situação encobre a abstração, implicando o que se nomeia "mimese".

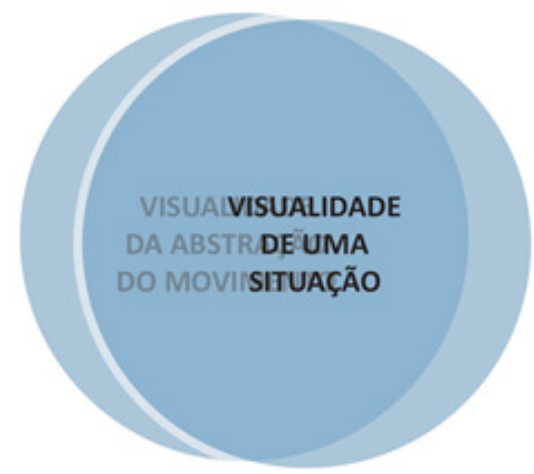

Figura 10: Absorção quase total de um enquadramento no outro

Uma atividade perfeitamente inscrita na visualidade do cotidiano, como cortar cebolas, estender uma toalha ou acender a lareira, para citar exemplos que aparecem em Stanislavski: "Deixem que os atores cruzem a cena e executem suas ações físicas segundo as necessidades da peça: procurem livros nas estantes, abram janelas, acendam uma lareira, e assim por diante (Stanislavski, 2005, p. 298- 299).
Também pode ser utilizada como um enquadramento plástico-corporal.

A plasticidade corporal e a plasticidade ficcional implicam camadas diferentes e evocam associações diferentes. Abre-se um campo de experimentação da inscrição do corpo na poética da cena e se observa uma necessidade de se criar repertório para se atualizar durante o jogo com os outros enquadramentos.

\section{Conclusão}

Transmitimos alguns conceitos que podem ajudar o ator a pensar o seu trabalho: incidência, enquadramento, vulnerabilidade são algumas funções mínimas e estruturais que servem a diversos tipos de arranjos, jogos diferentes, estéticas e poéticas diversas. Pretendeu-se introduzir estas noções, para que possam servir à Pedagogia do Ator. Com a interface com a psicanálise problematizamos o corpo como espaço de reverberações e não de imanência; descrevemos a função do foco já situada por autores como Stanislavski e Spolin, trazendo para a pauta o debate do material enquanto significante que incide, circula, desliza, empiIha. Destrinchamos o funcionamento da linguagem através de dois eixos, postulando que o processo de criação cênica se configura a partir desta estrutura: os arranjos abandonados e empilhados, presentes na ausência, deixam resíduos, assim como materiais que o ator não tem em foco, fazendo-se sentir enquanto reverberação, eco e, eventualmente, deslizando para o eixo horizontal. Situamos o olhar do ator como função que recorta superfícies e o olhar do espectador como um enquadramento. Problematizamos a operação da absorção dos enquadramentos, colocando a ação dramática e a ação física como enquadramentos 
diferentes, assim como a abstração do movimento ou som da voz, que pode ser reenquadrada em um universo diegético ou não e com graduações.

Referências

ALCÂNTARA, C. O trabalho do ator e a arte de ficcionar a si mesmo. Revista Brasileira de Estudos da Presença. Porto Alegre, vol. 3, n 3, p.902-922, 2013.

BARBA, E. A Canoa de Papel: Tratado de Antropologia Teatral. São Paulo: Hucitec, 1994.

GROTOWSKI, J. Sobre o Método das Ações Físicas. Palestra no Festival de Teatro de Santo Arcangelo (Itália), jun 1988. Disponível em: http://www.grupotempo.com.br/tex_grot.html (Acesso em 06/01/2013).

HAGEN, U. Técnica para o Ator: A Arte da Interpretação Ética. São Paulo, Ed. Martins Fontes, 2007.

KNÉBEL, M. El Último Stanislavski. Madrid, Ed. Fundamentos: 2005.

LACAN, J. O Seminário. Livro 23: O Sinthoma. Rio de Janeiro, Jorge Zahar Ed., 2007.

LACAN, J. O Seminário. Livro 20: Mais, Ainda. Rio de Janeiro, Jorge Zahar Ed., 1996.

MILLER, J. A. Lacan Elucidado. Rio de Janeiro, Zahar Ed., 2007
PAVIS, Patrice. Dicionário de Teatro. São Paulo, Perspectiva, 1999. SAUSURRE, Ferdinand. Curso de Lingüística Geral. São Paulo: Cultrix, 2006.

SAUSSURE, Ferdinand. Curso de lingüística geral. São Paulo: Cultrix, [s.d.]

SOLER, Collete. O "corpo falante". In: FINGERMANN, Dominique. (org.) Caderno de Stylus, n.1. Rio de Janeiro, Internacional dos Fóruns do Campo Lacaniano, 2010.

SPOLIN, Viola. Improvisação para o Teatro. São Paulo: Perspectiva, 1978. Jogos Teatrais: O Fichário de Viola Spolin. São Paulo: Perspectiva, 2000. . O Jogo Teatral no Livro do Diretor. São Paulo: Perspectiva, 2000. Jogos Teatrais na Sala de Aula. São Paulo: Perspectiva, 2007.

STANISLAVSKI, C. Minha Vida na Arte. Rio de Janeiro: Civilização Brasileira, 1989.

STANISLAVSKI, C. A Criação de Um Papel. Rio de Janeiro: Civilização Brasileira, 2005.

STANISLAVSKI, C. El trabalho de actor sobre si mismo - en el proceso creador de la encarnacion.

Recebido: 14/01/2016

Aprovado: 18/10/2016 